\title{
THE IMPORTANCE OF A BILL OF RIGHTS IN NORTHERN IRELAND AS A PROCESS: COMPARATIVE REFLECTIONS FROM SOUTH AFRICA
}

\author{
Dr Rachel Murray, Assistant Director, Centre for Human Rights, \\ Lecturer, School of Law, Queen's University Belfast*
}

\section{INTRODUCTION}

Discussion of a Bill of Rights often concentrates on its content and the document as a final product rather than the process of its adoption. The manner in which it was created, the method by which provisions were written and the compromises accepted, as well as the involvement of the society that it is intended to serve are important considerations in an analysis of the success of a Bill of Rights and may go some way to ensuring respect and implementation for the final product is achieved.

South Africa is perhaps one of the most famous examples of a jurisdiction which has recently undergone a transition and adopted a constitution including a Bill of Rights which is respected throughout the world. As Northern Ireland is now going through a similar process, this paper aims to compare this situation with the process of adopting a constitution and Bill of Rights in South Africa. This is not to argue that what applied in South Africa can automatically apply in Northern Ireland, ${ }^{1}$ but "comparison between the two cases thrives". ${ }^{2}$ Indeed prominent individuals involved in the peace process have been South African and there have been many works which have made such associations. ${ }^{3}$

* I would like to thank David Capper, Barbary Cook, Aideen Gilmore, Laura Lundy, Kieran McEvoy, John Morison, Christina Murray, Rachel Rebouche, Paddy Sloan and Frans Viljoen for their help and suggestions on this paper. This paper is a revised and developed version of a speech delivered to a conference organised by the Northern Ireland Human Rights Commission, "A Bill of Rights for Northern Ireland, Comparisons with South Africa", 16 December 2000.

1 C McCrudden, "A Northern Ireland Bill of Rights: Some Issues for Discussion", unpublished, on file with the author, 8 .

2 On the utility of comparisons, see Guelke who notes differences between South Africa and Northern Ireland, A Guelke, Inaugural Lecture, Queens University Belfast, 2001, p 2.

3 Guelke also notes comparisons made by Republicans with South Africa and colonisation, stating that "the question that arose was how was Republican violence to be legitimised in such circumstances? This is where analogies with other conflicts came in. Two received most attention in Republican propaganda: South Africa and the Middle East, pairing the IRA with the ANC and the PLO respectively", Guelke, ibid, p 9. See, for example: T Mitchell, Native versus Settler: Ethnic Conflict in Israel/Palestine, Northern Ireland and South Africa (2000); M Suzman, Ethnic Nationalism and State Power: The Rise of Irish Nationalism, Afrikaner Nationalism and Zionism (1999); C Knox and P Quirk (eds), Peace Building in Northern Ireland, Israel and South Africa (2000). 
In April 1998 the British and Irish governments signed the Belfast Agreement, ${ }^{4}$ and later the British government enacted in national law the Northern Ireland Act 1998. The Agreement called for the establishment of a Northern Ireland Human Rights Commission and in its section on "Rights, Safeguards and Equality of Opportunity"5 required it to:

"consult and to advise on the scope for defining, in Westminster legislation, rights supplementary to those in the European Convention on Human Rights, to reflect the particular circumstances of Northern Ireland, drawing as appropriate on international instruments and experience. These additional rights to reflect the principle of mutual respect for the identity and ethos of both communities and parity of esteem and - taken together with the European Convention on Human Rights - to constitute a Bill of Rights for Northern Ireland". ${ }^{6}$

In this regard the Commission was required to consider "the formulation of a general obligation on government and public bodies fully to respect, on the basis of equality of treatment, the identity and ethos of both communities in Northern Ireland; and a clear formulation of the rights not to be discriminated against and to equality of opportunity in both the public and private sectors." ${ }^{7}$ The Commission is to submit its advice to the Secretary of State for Northern Ireland. ${ }^{8}$

South Africa underwent a process of drafting first an Interim Constitution of 1993 which contained 34 constitutional principles from which the final constitution could not deviate. ${ }^{9}$ This Interim Constitution was drafted by unelected politicians through the CODESA process, ${ }^{10}$ a procedure "widely criticised for being undemocratic, restricted to a narrow elite and lacking transparency"11 and for being contrary to the views of some of the

4 The Belfast Agreement: An Agreement Reached at the Multi-Party Talks on Northern Ireland, Command Paper, Cm 3883.

5 Ibid, Strand 6.

6 Ibid, Strand 6, paragraph 4.

7 Ibid.

8 Northern Ireland Act, s 69(7).

9 H Corder, "Towards a South African Constitution" (1994) 57 MLR 491, at 515, notes that these principles were a "striking demonstration of the power of those negotiating parties. . . which distrust the democratic credentials of a future government affected by the majority". These were essential in any analysis of the final constitution.

10 Convention for a Democratic South Africa. This began in late 1991 with meetings between government and the ANC, and continued with the Multi Party Negotiating Process in March 1993, although some parties refused to participate. Technical Committees, of which there was one on fundamental rights, were established composed of non-party experts which helped to solve contentious issues, S Gloppen, South Africa: The Battle Over the Constitution (1997), Chapter 9.

11 Ibid, 256 
population. ${ }^{12}$ The Final Constitution was drafted after the multiparty elections in $1994^{13}$ and adopted finally in $1996 .{ }^{14}$

\section{THE DRAFTING PROCESS}

In March 2000 the Northern Ireland Human Rights Commission launched a consultation process on the Bill of Rights ${ }^{15}$ which, it is submitted, has taken place in two stages. Firstly, a general consultation was undertaken until early 2001 and secondly, the Commission published in September 2001 a draft Bill of Rights for public consultation. Consideration and comment was called for until 1 December 2001. The Commission was then to produce its advice to the Secretary of State by February 2002. ${ }^{16}$

By the end of 2000 the Commission had undertaken a number of activities to encourage wide participation on examining the content, status and implementation of a Bill of Rights. These included ${ }^{17}$ producing pamphlets on specific issues such as criminal justice, education, equality, culture and identity, language, social and economic rights, victims and implementation; developing a web-site on the Bill of Rights; and running a series of programmes to train trainers in human rights. It organised a billboard campaign "Who Needs Human Rights? All of Us", in some locations in Northern Ireland at over 40 advertising sights; gave talks to local groups and held a conference. ${ }^{18}$ The Commission also encouraged individuals to run their own working group or event.

To evaluate the success of this consultation, comparisons with the similar stage of the process in South Africa are useful. Whilst it is acknowledged that the Interim Constitution played an essential role in shaping the Final Constitution, ${ }^{19}$ it is the public consultation process which took place on the

12 Such as right wing groups, H Ebrahim, The Soul of a Nation: Constitution-Making in South Africa (1998) p 172. See also Corder op cit at note 9, 515.

13 Amendments to the constitution before elections brought the Inkatha Freedom Party (IFP) and others into the election process.

14 The Constitution had to be certified by the Constitutional Court to ensure that it satisfied the 34 constitutional principles. It was initially rejected. See $R e$ : Certification of the Constitution of the Republic of South Africa, 19961996 (4) SA 744 (CC), CCT23/96, 6 September 1996; Certification of the Amended Text of the Constitution of the Republic of South Africa 1996, CCT 37/96 (4 December 1996). The Court invited submissions from persons on whether there was violation with the principles. Hearings were held in which all political parties except the ANC participated. Gloppen, op cit note 10,212 argues that this gave the impression that the constitution was partisan.

15 See plans set out in Northern Ireland Human Rights Commission, Making a Bill of Rights for Northern Ireland (2000) p 4.

16 There is some possibility now that the consultation process may be extended.

17 This list is not intended to be exhaustive.

18 The conference from which this paper is taken, op cit note *.

19 Gloppen op cit note 10,3. The Constitutional Court did not certify it, rejecting it in relation to the Bill of Rights for failing to entrench rights sufficiently, a lack of procedures for constitutional change, that the state of emergency provision went too far, derogable conditions were not justified and it did not recognise the employer's right to collective bargaining. The IFP joined the amendment process whereby the Constitutional Assembly discussed only those aspects raised. The 
Final Constitution which, it is argued, helped to instill a sense of ownership in the final document. As with the process in Northern Ireland, in South Africa general consultation was undertaken first before comments were asked on specific drafts. This process took place in South Africa under the auspices of the Constitutional Assembly, a body of elected MPs. ${ }^{20}$ The first stage of the Constitutional Assembly's consultation process was perceived to have been extensive ${ }^{21}$ and involved, among other things: poster campaigns; programmes and broadcasting on the television and radio; dissemination of leaflets to homes directly and other areas such as taxi ranks; and the holding of workshops with key players, political bodies, organisations, schools, and the general public. There were also outreach programmes with local communities. A total of 1,000 workshops and meetings were held and they were estimated to have reached nearly 100,000 people.22 Public hearings were also held with key persons on specific issues including the judiciary, land rights, children's rights, women and socio-economic rights. ${ }^{23}$ There were also a series of petitions on specific questions, such as what should be the official language; should the death penalty be available; should South Africa be a secular state; should abortion be permitted; whether sexual orientation should be expressly included within a non-discrimination clause; whether animal rights should be protected in the Constitution; and whether there should be a right to own firearms. ${ }^{24}$ Nearly two million signatures on these petitions were received. ${ }^{25}$ Submissions were also invited from individuals and organisations and nearly 13,500 were received: 10 per cent from organisations, some from political parties, but most from individuals. ${ }^{26}$ There was a newsletter, "Constitutional Talk", which contained issues on the Constitution, drafts, invited submissions and which was distributed freely. ${ }^{27}$ An internet site was established with key documents, drafts and public statements on the process and a phone line was set up to hear people's views.

A South African organisation, Community Agency for Social Enquiry (CASE), undertook a survey for the Constitutional Assembly to assess the extent of the participation and it found that the media campaign had reached 65 per cent of the population in three months. ${ }^{28}$ Despite some scepticism about the success of a constitution and whether in fact people were clear on what a constitution meant, the process was extensive and reached many

document was sent back to the Constitutional Court and adopted in December 1996, op cit note 14.

20 The Constitutional Assembly of 490 members was elected by proportional representation. The ANC had most seats, but just short of enough to adopt the Constitution on its own. There was a central body of a 46 member multi-party Constitutional Committee, a Management Committee of 12 and six Theme Committees.

21 Ebrahim op cit note 12, 242 notes that this was done through liasing with the community, media and advertising.

22 Gloppen op cit note 10, 258.

23 Ibid.

24 Ibid, 257

25 Ibid.

26 Ibid, 258.

27 Ibid.

28 Ebrahim op cit note 12, 243. 
people. ${ }^{29}$ The action taken during the first stage in Northern Ireland pales in comparison. The same degree of awareness and inclusivity cannot be said to have been achieved by the Northern Ireland Human Rights Commission after the first stage of its process.

At its second stage of consultation, the Northern Ireland Human Rights Commission produced a Draft Bill of Rights for consultation in September until December 2001 during which time it said it would undertake "widespread public consultation on the Commission's draft proposals". ${ }^{30}$ The Commission again held numerous public meetings in each district council area, as well as events on specific issues such as women's rights, disability and sexual orientation. There were television advertisements, billboards on bus shelters and supplements produced in local newspapers. It is not clear, however, the extent to which the public awareness and knowledge of the Bill of Rights had increased, but there were more submissions received by the Commission during this period than during the first stage of consultation. Children and youth appear to have been well consulted and many have praised the work carried out by the Commission to explain the Bill of Rights to young persons. It would still appear, however, that there were misconceptions about the role of a Bill of Rights and the power it gave to the courts. Local human rights organisations, schools and other individuals have also developed their own ways of highlighting the process, although sometimes through their own initiative rather than being prompted by the Commission. ${ }^{31}$ It is still possible that the Secretary of State after receiving the Commission's proposals will undertake a further consultation process (as happened with Patten Report, Criminal Justice Review and others for two months) before putting drafting legislation before Parliament (probably Autumn 2002, early 2003). ${ }^{32}$

This second stage of consultation in South Africa was important for public participation. There a Refined Working Draft was distributed in October 1995 which gave options for provisions, explanations and was a working draft of the constitution. Over $4.5 \mathrm{~m}$ copies of this document were distributed around the country. ${ }^{33}$ A closing date was set for submissions from the public to be the end of February 1996 (four months later). A Media Campaign supported the distribution and invited further submissions on the specific draft. Other materials on the constitution were also distributed to help focus

29 Sarkin notes in relation to the process in South Africa, "while the statistics show a high response level to the invitation to participate, the extent to which public comment impacted on the final text remains unclear. The CASE enquiry revealed that 41 per cent of respondents believed that their submissions would be treated seriously, with people living in rural areas having the most faith and white people having the least". He also notes "the fact that the text was finalized by consensus reflects a remarkable achievement and much of the credit must go to a willingness, particularly on the part of the majority part, to accommodate the concerns of others and allay minority fears", J Sarkin, "The Drafting of South Africa's Final Constitution from a Human Rights Perspective", (1999) 47 American Journal of Comparative Law, 67, at 71 and 86.

30 See <http://www.nihrc.org/files/BoR_15.htm>

31 See, for example, initiatives by the Committee for the Administration of Justice (CAJ), 〈http://www.caj.org.uk>.

32 See <http://www.caj.org.uk>

33 Ebrahim op cit note 12, 194. 
submissions. The success of this second campaign has been noted with the receipt of nearly 1,500 submissions and nearly 250,000 petitions. ${ }^{34}$ Although there was some scepticism about the extent to which these submissions were actually taken on board in the final text, surveys again noted that whereas the majority of the population, 76 per cent, heard of the process through the media, some 12 per cent had obtained the information by word of mouth, suggesting that it had indeed generated public debate. ${ }^{35}$

In South Africa it was questioned whether it "was the content of the submissions of interest to the constitution-makers or only the fact that the submissions were made?"36 It was found that there were difficulties in dealing with the amount of material obtained, how to treat the various submissions and whether they were to be seen as representative. It has been pointed out, for example, that it is necessary to measure access to information for one section of the community rather than the other in order to see the representativeness of the submissions. It was difficult to consider whether the fact that a disproportionate number of the submissions came from the well-educated middle class rendered the final document less representative. ${ }^{37}$ In South Africa many organisations were asked to make submissions, but it is questioned whether these submissions "from organisations, particularly from central stakeholder, organisations with links to political parties, and organisations with specialised knowledge of the matters under consideration, appear to have fed into the process in a meaningful way. . . . However, the problem of representivity - which organised interests that are allowed to influence the negotiations-remains". ${ }^{38}$ Of those submissions from the public, it was noted that some were not focused and were very broad.

It has been said of the process in South Africa that it was "impossible to establish the precise extent to which the submissions from the public influenced the negotiation process and the constitution itself. There are too many interacting factors, too many possible patterns of influence and only tentative conclusions can be drawn". ${ }^{39}$ Having said this, however, at the second stage in South Africa, when comments were called on specific drafts, the submissions were seen to be more focused and less in number. These submissions were copied to the Committees, summarised and presented as end notes to the Draft Constitution sections: "This more manageable form

34 Ibid. During this time some behind the scenes negotiations were made among parties where agreement had been difficult to reach otherwise. Murray argues that although initially the process was open, it was essential that politicians chose to have bilateral meetings among themselves, on issues such as language rights and property, given the deeply divided nature of the society, C Murray, "A Constitutional Beginning: Making South Africa's Final Constitution", (2001) University of Arkansas at Little Rock Law Journal, 11. See also C Murray, "Negotiating beyond Deadlock: From the Constitutional Assembly to the Court" in $\mathrm{P}$ Andrews and $\mathrm{S}$ Ellmann (eds), The Post-Apartheid Constitutions: Perspectives on the New South Africa's Basic Law, (2001).

35 Ebrahim op cit note 12, 358.

36 Gloppen op cit note 10, 259 questions whether people were being fooled into believing that their participation was worthwhile.

37 Ibid.

38 Gloppen op cit note 10, 260.

39 Ibid. 
greatly increased the accessibility of the submissions and their probability of being taken into consideration". ${ }^{40}$ Thus, although "there are few signs indicating that the material content of the submissions from the public were utilised or systematically and seriously considered by the drafters at [the initial] stage. On the other hand, a certain influence cannot be ruled out" ${ }^{41}$

After the second stage of consultation on the specific draft document from the Commission in Northern Ireland there were criticisms that the Human Rights Commission has failed to generate this wide public involvement. A similar time period in which to undertake consultation in Northern Ireland, in total around one and half to two years, ${ }^{42}$ cannot justify the apparently limited impact it has had, particularly when one compares its population of around 1.5 million with South Africa's 40 million at that time.

\section{THE APPROPRIATENESS OF USING HUMAN RIGHTS AS A TOOL OF POLITICAL CHANGE}

The purpose of a Bill of Rights will vary depending upon the political, social and cultural context of the particular society. ${ }^{43}$ One aim of a Bill of Rights should be to check "the political power of the majority", ${ }^{44}$ whoever they may be, now and in the future. ${ }^{45}$ Such a document should therefore be for the protection of all persons, not just those who are or who consider themselves oppressed or discriminated against in the present situation, but those who may be so in the future. ${ }^{46}$ In addition, by ensuring as wide a participation and, therefore, as many views, as possible there is an increased likelihood that there will be a better Bill of Rights. ${ }^{47}$

Some have questioned the role of law, and human rights law, in dealing with political change, one of the arguments being that it may instead seek to

40 Gloppen op cit note 10, 261.

41 Ibid.

42 The deadline for producing the South African Constitution was two years from the first session of Parliament, namely 10 May 1996.

43 For example, it has been argued that the political purposes of the Canadian Charter of Rights and Freedoms were to ensure national unity and to "guarantee" human rights, P.H Russell, "The Political Purposes of the Canadian Charter of Rights and Freedoms", (1983) 61 Canadian Bar Review, 30.

44 A Cockrell, "The South African Bill of Rights and the 'Duck/Rabbit", (1997) 60 MLR 513, at 529.

45 Ibid. See also, for example, W.J Brennan, “Why have a Bill of Rights?”, (1989) 9 OJLS 427.

46 Cockrell, op cit note 44, 529. Cockrell also notes the quotation from Judges Chaskalson P and Didcott J in S v Makwanyane and Another, 1995 (3) SA 391 (CC), para 88 at $431 \mathrm{C}-\mathrm{E}$, that "the very reason for establishing the new legal order. . . was to protect the rights of minorities and others who cannot protect their rights adequately through the democratic process", and further, "to withdraw certain subjects from the vicissitudes of political controversy, to place them beyond the reach of majorities and officials and to establish them as legal principles to be applied by the courts".

47 A Sachs, "Towards the Constitutional Reconstruction of South Africa", (1986) 2 Lesotho Law Journal 12; see Gloppen op cit note 10, 257. 
entrench the status quo. ${ }^{48}$ For example, in relation to South Africa, it was said that rights language was used by the ruling white minority to advance protection of their property interests thus making it difficult for land issues to be resolved properly. ${ }^{49}$ Human rights, and a Bill of Rights, can be, as Mutua argues, "a double-edged sword: it can be used both as a weapon and as a shield" 50 and, therefore, in relation to South Africa it was argued "the protection of these interests through the new constitutional order in effect binds the ANC and robs it of any ability to carry out major reforms". ${ }^{51}$ I would not, however, take such a despondent view, if a Bill of Rights is seen as part of the process to a more just society, rather than the end result in itself. Indeed, whilst other action will also be necessary, ${ }^{52}$ such as changes to institutional structures, ${ }^{53}$ human rights themselves cannot hold all the answers. ${ }^{54}$

Inevitably a Bill of Rights will be a compromise, ${ }^{55}$ as Christine Bell has stated, human rights are "both forward - and backward - looking". ${ }^{56}$ There

48 R Hirschl, "The Struggle for Hegemony: Understanding Judicial Empowerment Through Constitutionalization in Culturally Divided Polities", (2000) 36 Stanford Journal of International Law 73, at 75.

49 "While rights discourse had the power to galvanize the oppressed and garner the sympathy of some segments of the middle and upper classes during the struggle against official apartheid, the Mandela government's near total dependence on rights discourse as the tool for the transformation of the legacy of apartheid is a mistake. First the double-edged nature of rights language has already become evident in South Africa. The new constitutional rights framework has frozen the hierarchies of apartheid by preserving the social and economic status quo", M wa Mutua, "Hope and Despair for a new South Africa: The Limits of Rights Discourse", (1997) 10 Harvard Human Rights Journal, 63, at 68 and 83.

50 Ibid, $\mathrm{p} 112$.

51 Ibid, p 112.

52 “. . . rights discourse does not and probably cannot provide us with the criteria for deciding between conflicting claims of right. In order to resolve rights conflicts, it is necessary to step outside the discourse. One must appeal to more concrete and therefore more controversial analyses of the relevant social and institutional contexts than rights discourse offers; and one must develop and elaborate conceptions of and intuitions about human freedom and self-determination by reference to which one seeks to assess rights claims and resolve rights conflicts", K Klare, "Legal Theory and Democratic Reconstruction: Reflections on 1989", (1991) 25 University of British Columbia Law Review, 69, at 101.

53 As Gilbert Marcus argues, in relation to the Constitutional Court in South Africa, "the creation of a special court was considered imperative. Apartheid had resulted in distortions in all institutions of public life", G Marcus, "A Bill of Rights for Northern Ireland: Lessons From South Africa", July 2000, p 3 (on file with author). J Sarkin, "The Development of a Human Rights Culture in South Africa", (1998) $20 H R Q, 628$. Sarkin, op cit note $29,86$.

54 As McEvoy has noted, for example, in relation to Northern Ireland, "with regard to the issue of disputed marches, while it may be conceptually useful to remind both marchers and residents groups that one element of their dispute is a clash of rights, the human rights framework can make no pretence to have all the answers in such a dispute", K McEvoy, "Human Rights, Humanitarian Interventions and Paramilitary Activities in Northern Ireland", in C Harvey, Human Rights, Equality and Democratic Renewal in Northern Ireland (2001) p 215, at 246-247.

55 Corder op cit note 9, 514, notes that the South African Constitution's provisions on rights were "reached after much dispute and vacillation between the major 
will be at least two extreme positions pulling in opposite directions: "law and constitutions in such times draw their sense of justice from past human rights abuses, and notions of the rule of law and constitutional interpretation are shaped by the attempt to construct a different future". ${ }^{57}$ Human rights law, therefore, plays "a role in mediating between past and future" ${ }^{58}$ In addition, it is also likely that any agreement reached among the people and Commission in Northern Ireland may be watered down further once it is submitted to the British government, as was only too clear from the Patten proposals and their subsequent translation into the Police (Northern Ireland) Act $2000 .^{59}$

Although the validity of a Bill of Rights as part of a state/community building process has been questioned, ${ }^{60}$ it is clear that violations of human rights contribute to and exacerbate a conflict and thus part of the solution will require respect for human rights. ${ }^{61}$ In this way human rights can be part of a move towards a more democratic process ${ }^{62}$ and "international law and law in general can provide a powerful tool to individuals and communities struggling to create viable and accountable political, economic, social and cultural institutions". ${ }^{63}$

parties", and have been criticised "on the basis of particular needs or programmes of such groups were not accommodated unreservedly".

56 C Bell, Peace Agreements and Human Rights (2000) p 303.

57 Ibid.

58 Ibid.

59 See P Hillyard and M Tomlinson, "Patterns of Policing and Policing Patten", (2000) 27(3) Journal of Law and Society, 394-415; Committee for the Administration of Justice (CAJ) "CAJ Dismayed by Patten Legislation", 16 May 2000, <http://www.caj.org.uk/press/20000516.html>.

60 See J Morison, "Democracy, Governance and Governmentality: The Role of the Voluntary Sector in the Democratic Renewal of Northern Ireland", in C Harvey, Human Rights, Equality and Democratic Renewal in Northern Ireland (2001) p 249. See also, G H Fox and B R Roth, Democratic Governance and International Law (2000); C Harvey, "Democracy in Transition: Mainstreaming Human Rights and Equality in Northern Ireland", (1999) 4 Journal of Civil Liberties, 307; C Palley, "Constitutional Devices in Multiracial and Multireligious Societies", (1968) 19 NILQ, 377

61 As Brice Dickson states, "a failure on the part of the authorities to address human rights concerns made reaching a political settlement between the parties which did not support violence all the more difficult", B Dickson, "The Protection of Human Rights: Lessons from Northern Ireland", [2000] EHRLR 213, at 213; McEvoy op cit note 54, 215. See also, Bell op cit note 56.

62 Morison notes the potential of a Bill of Rights to "deliver democratic process" and that advocates use human rights as a way of ensuring democracy, "widening political space" and to "hear voices outside traditional politics", Morison op cit note 60, 269-271.

63 R.C Slye, "International Law, Human Rights Beneficiaries and South Africa: Some Thoughts on the Utility of International Human Rights Law", (2001) 2 Chicago Journal of International Law, 59, at 77. As Bell noted in relation to Northern Ireland, "the human rights dimension signals a fundamental change in the nature of the state. It is to be a state which recognizes both nationalist and unionist aspirations and identities as equally legitimate. In South Africa human rights protections are central to what is in essence a transfer of power. Human rights provide a new legitimacy to a new regime, but also aim to establish the new 
There is a role, therefore, that a Bill of Rights can play in uniting a disparate and divided society and in this sense the manner in which it is adopted is important, "the symbolic importance of such instruments and their potential to foster a striving for common goals and aspirations depends greatly on the degree to which the drafting process has been inclusive and legitimate. Inclusivity can inspire a sense of national ownership; a non-inclusive process can be a source of tension and further division". ${ }^{64}$

In this regard, the involvement of not only the key political players such as politicians and public organisations, but also the public as a whole in this project, is essential to the democratic and peace building process. The process of drafting itself can promote understanding between persons, namely create an awareness and perhaps appreciation of the "other" dialogue and can actually stimulate discussion and the development of a civil society. ${ }^{65}$ In addition, ensuring that all persons are involved in deciding the content of a Bill of Rights increases the likelihood that there will be a sense of ownership of the resulting document. ${ }^{66}$ It is submitted that the drafting process should be seen as part of the peace process as a whole, as part of the gradual transformation to reconciliation and a just society. ${ }^{67}$ Enabling and encouraging all persons to be involved may actually help to ensure that the end product is actually respected and upheld. ${ }^{68}$

There are a number of issues, however, that go to the heart of the success of the process in Northern Ireland.

\section{ROLE OF POLITICAL REPRESENTATIVES IN THE PROCESS}

\section{(a) Role of the Commission}

Unlike Northern Ireland, where the Human Rights Commission was mandated with the task of advising on the Bill of Rights, the process of drafting the constitution and its Bill of Rights in South Africa took place within a political process, under the CODESA process and then the Constitutional Assembly where parties (although the IFP did withdraw) were represented. There were some complaints that the Constitutional Assembly, despite being politically representative, asked for information but was not really prepared to engage in debate and it has been argued that "internally it seems that few organisations in civil society made serious attempts to draw

regime as multiracial or pluralist, and capable of protecting rights regardless of ethnicity, rather than a mirror image of its predecessor", Bell op cit note 56, 294.

64 Sarkin, op cit note 29 , at 86

65 Ibid.

66 Ibid.

67 Ibid, see also Gloppen op cit note 10, 64 .

68 Gloppen op cit note 10, 65: "participation in the creation [of a constitution] works to kindle an obligation towards it". The paper produced by the Victims' Rights Working Group also notes that a "Bill of Rights can be seen as one of the fundamental ways of establishing a new legitimacy for the rule of law. It is a building block of a new society that is designed to transcend and resolve the conflict of the past”, Northern Ireland Human Rights Commission, Bill of Rights. Victims' Rights Working Group Report, January 2001, 1. 
their members into meetings or discussions about the writing process". ${ }^{69}$ However, those who may have been sceptical of how the process would benefit them ${ }^{70}$ at least felt they had representatives involved in it from the start who had considerable leverage in the negotiations, enabling them, for example, to negotiate over contentious issues such as the protection of private property and protection of some language (Afrikaans) schools. ${ }^{71}$ This has not been the case for Northern Ireland where even the Northern Ireland Assembly has had little role to play. Instead, the development of the Bill of Rights by a non-elected body, outside of the political structure with all of the preconceptions about its membership, served only to continue the perception that human rights are a republican/nationalist agenda.

In addition, the process in Northern Ireland has also been criticised for being the domain of NGOs and the human rights community which, again, are neither representative nor, it is argued, objective. Such arguments, about the role of non-elected individuals promoting such constitutional change, are not new ${ }^{72}$ and some have argued "NGOs, acting individually and in networks, often wield influence on decision-making "behind closed doors" and without pluralistic participation", ${ }^{73}$

The Human Rights Commission was mandated by the Belfast Agreement to "consult and to advise on the scope for defining, in Westminster legislation, rights supplementary to those in the European Convention. . ., to reflect the particular circumstances of Northern Ireland". What "consult and advise" meant was not entirely clear and some have queried whether the Commission has overstepped its mark by going as far as it did and drafting an actual document. I believe, however, it is commendable that the Commission interpreted this in a broad sense to try to obtain as many views as possible. However, beyond this issue its mandate is not entirely clear. Is it merely to collect and facilitate the views of the people of Northern Ireland for presentation to the Secretary of State? Is it, in addition, to set some minimum standard of human rights for the jurisdiction beyond which, even if

69 Gloppen op cit note 10, 262.

70 Constitutional Assembly Annual Report 1996, 71 and 75, noted that comparatively less proportion of the white section of the population said they had learnt something from the process, <http://www.polity.org.za/govdocs/constitution/ca/ANREPORT/Ca95_96.pdf>; see also Ebrahim op cit note 11, 245.

71 M.A Burnham, "Constitution Making in South Africa", Boston Review, University of Illinois Press, <http://bostonreview.mit.edu/BR22.6/burnham.html>.

72 "The rise of civil society presents a paradox to human rights advocates. On the one hand, civil society can promote human rights norms and raise the concerns of unheard voices. ... On the other hand, transnational civil society may undermine this norm of democratic governance since voluntary associations are wholly unaccountable to any sovereign and, thus, may act in a manner contrary to democratic principles", J Mertus, "From Legal Transplants to Transformative Justice: Human Rights and the Promise of Transnational Civil Society", (1999) 14 American University International Law Review, 1335, at 1340.

73 Ibid, 1372-1373. See also C Tracy, "The Growing Role of Non-Governmental Organizations", (1995) 89 American Society of International Law Proceedings, 413; T Van Boven, "The Role of Non-Governmental Organizations in International Human Rights Standard Setting: A Prerequisite for Democracy", (1990) 20 California West Journal of Internati.onal Law, 207. 
public opinion is contrary to it, any Bill of Rights must not fall. Its nonpolitical status and human rights expertise would support this latter view. This should be one of the advantages of having the Bill of Rights drafted by those who are not politicians. This is indeed the approach the Commission seems to have (rightly I would argue) adopted, as it has stated in its consultation document:

"the purpose of this consultation paper is to draw on the many submissions the Commission has already received and to set out the Commission's initial views on what rights a Bill of Rights should include and how they could be enforced. On some issues the Commission has reached preliminary conclusions. On others it has not yet made up its mind and has therefore set out what it sees as the main options. But it wants to have your views on all the issues involved before it makes its final recommendations to the Government". ${ }^{74}$

In addition, the Commission has argued that its obligations under section 69(3) of the Northern Ireland Act permit it to take this wider view. Similarly, there have already been examples of where the Commission has supported human rights principles even in areas which do not obtain the support of many of the population in Northern Ireland, for example, by funding research into treatment of individuals on the basis of their sexual orientation in Northern Ireland despite criticisms, ${ }^{75}$ and involving representatives of the gay, lesbian and trans minorities in the Working Groups in Northern Ireland whose views were reflected in the resulting papers. ${ }^{76}$ Similarly, when petitioned on whether the Constitution should expressly include sexual orientation in the anti-discrimination clause, 17,000 South Africans out of a million voted against its inclusion. ${ }^{77}$ Despite this, it was eventually protected within section 9 of the Constitution and there have now been cases before the Constitutional Court upholding nondiscrimination on this ground. ${ }^{78}$ The decision to include such protection in the South African constitution, which appears to go directly against the wishes of a significant number of persons, suggests that the will of the

74 Northern Ireland Human Rights Commission, Making a Bill of Rights for Northern Ireland. A Consultation by the Northern Ireland Human Rights Commission (2001) p 7.

75 For example, M Coleman, "Protest Against Gays", Belfast Telegraph, 11 June 1999; L Deeny, "Gays Vow to Defy Bigots", Belfast Telegraph, 21 February 2001; "Gays have Bullied the Entire Nation", Belfast Telegraph, 15 February 2000.

76 The general non-discrimination clause in the Equality Working Group's paper mentions sexual orientation explicitly as one of the grounds on which there should be no discrimination, Northern Ireland Human Rights Commission, Bill of Rights. Equality Working Group Report, January 2001, para 4, noting on p 3 that the issue of equality "goes beyond the nationalist/unionist political divisions. ..". The Report draws upon the South African Constitution provisions on discrimination, amongst others. See also, Northern Ireland Human Rights Commission, Bill of Rights. Culture and Identity Working Group Report, January 2001.

77 Gloppen op cit note 10, 257.

78 See for example, National Coalition for Gay and Lesbian Equality and others v Minister of Justice and others, CCT11/98, 9 October 1998. See also more widely, Hoffman v South African Airways, CCT17/00, 28 September 2000. 
people need not always be the determining factor in deciding the content of the Bill of Rights.

\section{(b) Role of the Working Groups}

That the Commission's mandate is not clear was also reflected in the position of the Working Groups. The Commission in Northern Ireland appointed Working Groups to consider a number of specific issues, namely victims' rights, culture and identity, children and young people, language rights, equality, social and economic rights, education rights and implementation issues. The Working Groups were required to produce advice to the Commission by the end of February 2001, which it would consider along with submissions received from other organisations, individuals and the wider public. In South Africa the Constitutional Assembly appointed six Theme Committees from among its 490 members, one of which had the task of drafting the provisions on fundamental rights. ${ }^{79}$ These Theme Committees were composed of 30 persons nominated by political parties in proportion to their representation, with several chairpersons to ensure they were not dominated by one party. Their main role was to ensure the inclusive nature of the process by hearing submissions from all key persons. ${ }^{80}$ Some of the Committees were given a technical committee of experts to advise them. Submissions from the public and others were fed back into the Theme Committees to include in their discussions and drafts.

Because the Theme Committees were set up under the elected body of the Constitutional Assembly, they were therefore politically representative. This avoided some of the difficulties associated with the Working Groups in Northern Ireland which, although appointed for their expertise, have been criticised for not being sufficiently representative, not only politically but also of all sectors and communities in Northern Ireland. The result is that some argued this initial process in Northern Ireland was not impartial.

What also did not seem to be clear in Northern Ireland was the exact mandate of the Working Groups. They were eager to make it clear at the start of their remit that it would not be their role to initialise public debate. While this task then clearly fell to the Human Rights Commission itself, this left some uncertainty as to what exactly the Working Groups should be producing, namely, whether the aim was to produce explicit drafts of a Bill of Rights, or merely a collection of ideas. The former would presume some legal drafting, which, it appeared, some of the groups did not perceive themselves having the relevant expertise to do. The latter would suggest that some public consultation by the groups was required. This did not take place. Whilst it might appear to have been easier to leave this task to the Working Groups, this was not really feasible given their limited budgets ( $£ 2000$ per group) and the fact that all members of the group were undertaking this task on a part time voluntary basis.

79 There were Theme Committees on: the democratic state, structure of government, relationship between levels of government, fundamental rights, judiciary and legal systems, and specialised structures of government.

80 Ebrahim op cit note 12, 182. 
If the role of the Working Groups was merely that of experts to assist in drafting the Bill of Rights then this raises the question as to why, although some of the reports of the Groups were incorporated into the draft consultation document, for two of the groups: identity and community and language rights, the draft document of the Commission bears little relationship to the proposals offered by those Groups. Some have therefore questioned the purpose of asking these Groups to propose suggestions, where many took great pains to reach a difficult compromise, when their suggestions would be treated as any other. Whilst this might have been an important process for the individuals involved, the wider purpose is less clear.

\section{(c) The perceived nationalist/republican bias}

The Commission has also faced further difficulties in Northern Ireland as a result of the perception that human rights is a nationalist/republican agenda. This may not only be the result of the political ideology of the right and left but McEvoy $^{81}$ has also suggested that human rights law through the European Convention on Human Rights was used by the nationalist/republican movement as part of a campaign to internationalise their struggle, and thus, "human rights challenges offered the opportunity to embarrass British governments and to expose state abuses". ${ }^{82}$ Mageean and O'Brien note that although there was a shift in attention paid to human rights issues during the drafting of the Good Friday Agreement and that little attention was paid by nationalists to human rights in the process, "the experience of the nationalist community within the state of Northern Ireland was forcefully articulated in the language of rights as early as the beginning of the current conflict. Indeed, many would say that the violence of the state's reaction to that expression of discontent led to the re-birth of military republicanism and the subsequent violence", ${ }^{83}$

As a result human rights are themselves not associated with an objective approach which will guarantee protection to all parties but as a tool of a particular political belief. It was inevitable therefore, that the Northern Ireland Human Rights Commission was going to be perceived as a body which would pursue a nationalist/republican agenda and which would be

81 K McEvoy, "Law, Struggle and Political Transformation in Northern Ireland", (2000) 27(4) Journal of Law and Society, 542-571, at 557.

82 McEvoy also notes the perceived link between Republican violence and use of human rights, "the inability or unwillingness of the Stormont regime to respond to the demands of the civil rights movement contributed directly to the development of more confrontational strategies. . . . once Republican violence began in earnest, the primacy of armed struggle meant that. . . those advocating a rights-based analysis of the conflict were liable to be treated with suspicion as "partitionist", ibid, 568-569.

83 P Mageean and M O'Brien, "From the Margins to the Mainstream: Human Rights and the Good Friday Agreement", (1999) 22 Fordham International Law Journal, 1499 , at 1503 . They also note that the Irish government saw rights as central to the conflict, 1504. 
composed of sympathisers to that cause and a Bill of Rights as a republican document. ${ }^{84}$

Despite attempts to ensure that the membership of the Commission was representative of at least these two communities of Northern Ireland, these concerns still continue and the resulting feeling of alienation from the process by the unionist community has forced the Commission to consider alternative ways of including them and others traditionally opposed to the notion of human rights. ${ }^{85}$

In contrast, in South Africa "the need for a bill or charter of fundamental rights in a new constitution in South Africa was a point of almost unanimous agreement". ${ }^{86}$ Thus, although "the relationship between the newly democratic government in South Africa and international human rights law is, however, a complex one", 87 the Bill of Rights had the support of the white minority as it was seen as a way of protecting their property rights. Therefore, there seems to have been several reasons why this was the case including that the adoption of such was inevitable and could not be avoided and therefore, they started to see the benefits that a Bill of Rights could bring to them and that "without some guarantee of protection for the rights of

${ }^{84}$ Mageean and O'Brien state that "it is very likely that unionists within the talks process were left in little doubt that the extensive protections afforded to rights in the Agreement were there primarily to reassure nationalists who had suffered under both unionist and direct rule from London that the diluted but extant union that would emerge from the talks would be a safer place for them". However, although some unionists accepted human rights as important, this was "not mirrored in mainstream unionism. Contemplating serious change to the police, judiciary and criminal justice system would have constituted firm evidence that flaws existed within those institutions and that they had in some ways contributed to the conflict. ... To effect real change to the police was to accept the validity of the 'enemy's' perception of the police, and therefore to betray those who had stoutly defended the state through a quarter of a century of the worst political violence experienced in any Western sense since World War II. In one sense, it could be argued that mainstream unionism could only lose in the talks, and the question was really how much would be lost”, Mageean and O'Brien, ibid, 1509 and 1510.

85 See below, in relation to individual duties.

86 R Spitz and M Chaskalson, The Politics of Transition. A Hidden History of South Africa's Negotiated Settlement (2000) p 252. Spitz and Chaskalson note "the debate about fundamental human rights took place in the context of ideological and political power interests. Within the ideological context, three conceptual tensions stand out: between liberationism and libertarianism; progressivism and traditionalism, and feminism and patriarchy", p 253. As they note, liberationism referred to individual liberty and state intervention being restricted and liberationism "is associated with the tradition of "freedom fighting" in South Africa, and has come to emphasise equality and the need to bring about equality through political power". The Technical Committee expected that there would be "strident claims form those formerly excluded from power" and "those still clinging to office will attempt to preserve as much privilege and control over the process as they can". Yet, "the notion of a political power struggle is crucial to a basic understanding of the conflict surrounding the inclusion or formulation of certain fundamental rights".

87 Slye op cit note 63, at 61 . 
minorities, the previous ruling white minority government would not have relinquished power to an inevitably black-controlled majority government". ${ }^{88}$

\section{CONTENT OF A BILL OF RIGHTS}

The issue of what rights to include illustrates some of the difficulties of the process of drafting the Bill of Rights and have a part to play in the sense of ownership of the final document.

\section{General issues}

There was an attempt to use plain language rather than legal language in the Bill of Rights and Constitution as a whole in South Africa to ensure its accessibility to all persons. ${ }^{89}$ Despite concern from some legal quarters that this would render the document weak and open to legal challenge, the final document is considered to be a successful compromise. This experience would be useful in Northern Ireland where there have been criticisms that the draft Bill of Rights it is not accessible to the wider public. There were concerns, both, that some of the Working Groups were too legal in their approach, that the information is very much a paper exercise and was difficult to understand and, on the other hand, there were also fears from those within the Groups that they did not have the necessary legal expertise to draft such material. It would be useful if the Commission took on board expert assistance in drafting its final submissions to the Secretary of State in this respect.

\section{Economic, Social and Cultural Rights}

There has been considerable discussion as to whether to include economic, social and cultural rights as well as civil and political rights in a Northern Ireland Bill of Rights. In addition to the number of well argued reasons as to why economic, social and cultural rights should not be treated differently from civil and political rights, it has also been noted that the process of involvement of all sectors of the community necessitates that there should be both. ${ }^{90}$ Thus, "the narrower the range identified, the less likely it is that individuals will identify with the bulk of rights on the list. In particular, the more the rights specified are seen to appeal across the communities, the more

88 R J Goldstone, “The South African Bill of Rights", (1997) 32 Texas International Law Journal, 451, 452. Thus, "the former South African government, recognising that it was inevitable that minority rule would sooner or later have to give in to the demands for democratic government, flirted with the idea of protecting group rights. The government in this way hoped to maintain some of the privileges enjoyed for so many decades by whites", 455 .

89 The Constitutional Assembly decided that the constitution should be drafted in plain language and a plain language expert was involved in the process, see Murray op cit note 34, 12.

90 McCrudden op cit note 1, at 7 argues "modern constitutions now mostly contain an attempt to identify the basic values that a country is committed to .. recognising a common set of rights in a document that all can commit to, at least in part, is thus an important element in building a new society, providing the possibility of common identification by all with the basic document. For this reason it is important that the rights identified should not be too narrow in their focus". 
likely it will be that rights can be seen as something that binds the communities together rather than divides them". ${ }^{91}$

Similar arguments were raised in South Africa, indeed, the majority of members of the Technical Committee drafting the Interim Constitution and Bill of Rights "seem to have considered a full Bill of Rights fairer than one which accorded with the wishes of only one political party". In addition, just as there has been disagreement here over what constitutes "circumstances particular to Northern Ireland", so in South Africa at the stages of drafting the Interim Constitution it was not clear what was meant by "transition", as the Technical Committee was required to draw up a set of rights in the Interim Constitution which would be essential to fair elections. ${ }^{92}$ Thus:

"the conflict between "minimalists" and "maximalists" over the interim Bill of Rights became a microcosm of the negotiating process. . . At first the Technical Committee took the view that third-generation rights were not related to the transition, and therefore irrelevant to an interim Bill of Rights. In no time, however, the list of "essential" human rights had multiplied, and the minimalists were forced to review their position". 93

The Technical Committee would appear to have had some political pressure from the government to take a maximalist approach "this was their opportunity to draft the founding document of a human rights culture in South Africa and they took it". ${ }^{94}$ Thus:

"in many ways, and particularly in view of the explicitly political context in which discussions occurred, it made greater political sense to satisfy the largest possible number of parties by including rights on which they insisted, rather than alienate them from the negotiating process and undermine the principle of inclusiveness. Thus circumstances forced the ANC's

91 McCrudden, op cit note 1, at 7-8. Further, "a broad based list of rights can enable a set of common values to be committed that transcends consocialism, and offers an alternative vision of the future".

92 Spitz and Chaskalson, op cit note 86, at 259-260; Cockrell, op cit note 44, at 526. Corder op cit note 9, at 512 notes that similarly in South Africa there were also different views on the content of a Bill of Rights in the drafting of the 1996 Final Constitution. Some wished for a complete inclusion of all rights including economic, social and cultural and peoples' rights. Others, including the ANC wanted a democratically elected assembly to be free to draft whatever bill of rights it wanted, and wanted civil and political rights, in particular, free and fair elections. Corder notes, 513 "both the inclusion of certain rights, the exclusion of others and the precise formulations adopted were the direct product of political negotiations and agreement, with the government and the ANC being driving forces". He then adds that once people had got used to the idea of an interim constitution and national unity government "there was little difference of opinion over the inclusion and formulation of the commonly accepted civil and political rights".

93 Ibid.

94 Ibid, at 262. 
ideological commitment to maximalism to prevail over its political expedient minimalism". ${ }^{95}$

As a result the South African Bill of Rights does contain rights to adequate housing, health care, food, water and social security, education, language and culture. Although in the Interim Constitution these rights were given a limited place, they are extended upon in the Final Constitution. One of the other arguments against including such rights which was raised in South Africa and has been raised in Northern Ireland has been shown to be flawed, namely that they could not be challenged before courts. ${ }^{96}$ The argument was rejected by the South African Constitutional Court in its certification and given a recent case in the Constitutional Court concerning housing rights ${ }^{97}$ there are clear precedents for the contention that inclusion of such rights in a Northern Ireland Bill of Rights would be realistic and enforceable.

The inclusion of such rights in the draft consultation Bill of Rights by the Northern Ireland Human Rights Commission is to be welcomed and the Commission has recognised that it is clear that such issues cut across community divides and therefore can have a uniting purpose and their inclusion could help to generate a sense of ownership in the resulting document. These rights should therefore be embraced for these purposes.

\section{(c) Obligations of non-state actors?}

The Northern Ireland Human Rights Commission has considered using the notion of duties of the individual as a way of appealing to more right-wing ideology and sections of the community traditionally opposed to human rights. ${ }^{98}$ About $90 \%$ of those who have died during the conflict in NI were as a result of killings by paramilitaries ${ }^{99}$ and it has been argued therefore that the Bill of Rights should impose obligations not just on the state but also on non-state actors. As Brice Dickson has recognised, "this is the context against which the reaction of the state authorities has to be assessed. The context may not excuse the reaction but it does help to explain it". 100 The attempt to include this horizontal approach has been met with concern by human rights organisations for several reasons, particularly that the manner in which this is being promoted is to limit rights rather than enhance their protection. ${ }^{101}$

95 Spitz and Chaskalson, op cit note 86, at 262.

96 The Constitutional Court in its certification of the constitution noted that objections related to the fact that they weren't universally recognised. In response to this the Court held that the final constitution was not limited to the rights raised in the interim one, it could go wider and it could supplement rights with those which are not universally recognisable, see Certification of the Constitution, op cit note 14.

97 Government of RSA and others v Grootboom and others, Constitutional Court, CCT 11/00, 4 October 2000.

98 See also McCrudden op cit note 1, at 9 .

99 A Simpson, Murder Madness: True Crimes of the Troubles (1999).

100 Dickson op cit note 61, at 216.

101 "Talk of the need for a Bill of Rights and Responsibilities is misleading at best and dangerous at worst. It is misleading in that it suggests a rights culture is a culture of licence, where people are free to hurt and abuse others... Who would seek to invoke responsibility provisions? The only obvious contender is the state 
Comparisons with the South African experience would indicate that this was also a much debated issue ${ }^{102}$ in the drafting of the Interim Constitution. ${ }^{103}$ The issue was complex, "the underlying fear or hope, depending on which political viewpoint and constituency a party represented, being that without horizontality, corporations and companies would be able to "privatise" discrimination by keeping it beyond the reach of the state". ${ }^{104}$ Parties fluctuated over the horizontality issue in the Interim Constitution. Issues of concern against horizontality included the need to protect the privileges of the white and rich and stopping interference in the private sphere; fears that there would be a huge number of cases before courts, that employment practices would not be disturbed for whites, that discrimination in the private sphere could be prevented in other ways, and that horizontality would give too much discretion to the courts. Those arguments for horizontality included that it would prevent economic interests evading Bill of Rights requirements, would prevent discrimination in the private field and the "privatisation of apartheid". In the end horizontality was not included in the Interim Constitution, although it did find its way into the Final Constitution. As Spitz and Chaskalson note:

"ultimately, the fact that the Bill of Rights was to be of short term duration probably swung the outcome in favour of verticality: the practical arguments for legal certainty during the transition outweighed the desirability of exploring academic possibilities surrounding horizontal application. This would also help explain why horizontal application was chosen for the Bill of Rights in the final Constitution, where immediate practical concerns appeared to matter less than the long-term potential for the inculcation of a rights culture". ${ }^{105}$

In addition, in South Africa, as here, this issue reflected "a tension within international law between the legitimacy of the means used in an armed conflict (jus in bello) and the legitimacy of the ends for which an armed conflict is undertaken (jus ad bellum). Some in South Africa collapsed these two areas of international law and argued that the legitimacy of the fight against apartheid made every act committed in furtherance of that goal

itself', Committee on the Administration of Justice (CAJ), CAJ's Preliminary Submission to the Northern Ireland Human Rights Commission on A Bill of Rights for Northern Ireland March 2001 (CAJ, Belfast, 2001), p 2. As McEvoy argues, those lobbying groups who used the human rights framework in relation to paramilitary violence did not actually use human rights standards and did not look at state abuses, but networked with anti-terrorist groups and were funded by the government. He argues that the work of human rights organisations which focused on state abuses had an impact on paramilitary groups and explains why human rights bodies in Northern Ireland chose to focus on state abuses only. McEvoy op cit note 54, at 231-232. He also notes that the way of holding paramilitaries to account would be to apply humanitarian law and organisations such as CAJ were reticent to do so as this would make distinctions between who were legitimate and illegitimate targets, that it would cause arbitrary distinctions between loyalist and republican violence.

102 Slye op cit note 63, at 71.

103 Du Plessis and Others v De Klerk and Another, 1996 (3) SALR 850 P10 (CC).

104 Spitz and Chaskalson op cit note 86, at 268; Marcus op cit note 53, at 5.

105 Spitz and Chaskalson op cit note 86, at 279. 
legitimate". ${ }^{106}$ It was noted, therefore, that "if the Truth and Reconciliation Commission (TRC) adopted this position, one direct effect would have been that victims of violent acts committed by the anti-apartheid movement would not have been considered victims of a gross violation of human rights under the TRC legislation and thus would not be eligible for reparations. The TRC eventually adopted the traditional international law position, noting that while apartheid was a crime against humanity and the fight against it was just, certain acts of the anti-apartheid movement qualified as gross violations of human rights". 107

Indeed, the Constitutional Court in their certification of the Final Constitution rejected objections based on several grounds including the argument that the principle was not universally acceptable. The Implementation Issues Working Group in Northern Ireland considered this issue and took the South African experience on board. ${ }^{108}$

The consultation document of the Human Rights Commission has some recognition of this issue in its preamble, for example, which states "realising that each individual in Northern Ireland, having duties to other individuals and to the community to which he or she belongs, is under a responsibility to strive for the promotion and observance of the rights recognised in the present Bill of Rights". This appears to be a sensible approach which follows international standards and does not adopt the perspective of limiting rights which was initially feared.

\section{EVALUATION OF THE DRAFTING PROCESS}

As to whether the process created better understanding between peoples, both in South Africa and in Northern Ireland there was difficulty in obtaining the support of all members of the population. ${ }^{109}$ It was recognised in South Africa, however, that over particularly contentious issues, discussion was apparent: "Certain issues of great emotional value, such as the flag and the national anthem, were the subjects of huge numbers of submissions and much public debate", 110 even if it was difficult to see whether the process did lead to an understanding of the "other". ${ }^{111}$ What was clear in South Africa was that "acknowledgement of the value of public debate and of democratic processes as the legitimate approach to conflicts over the rules of politics, appear, however, to be widespread. This is indicated by surveys as well as by the marginalisation of the parties who chose to boycott parliamentary bodies". ${ }^{12}$ What was apparent in South Africa and in Northern Ireland was

106 Slye op cit note 63, at 71 .

107 Ibid, 71-72.

108 Northern Ireland Human Rights Commission, Bill of Rights. Implementation Issues Working Group Report. January 2001, para 11.

109 The IFP boycotted the negotiations in the Constitutional Assembly in March 1995 (after a disagreement on international mediation). Gloppen op cit note 10, at 208 notes that "the obvious problem with regard to the IFP boycott is, of course, the negative impact on the legitimacy of the constitution". The second stage of the constitution was finalised with the ANC and National Party as the main parties.

110 Gloppen op cit note 10 , at 263.

111 Ibid.

112 Ibid. IFP withdrew from the constitutional negotiations, although it did win seats in the election. Christina Murray argues that this undermined the Constitutional 
the enthusiasm and energy about the process, among the wider community. ${ }^{113}$ This led to debate and discussion.

Survey results in South Africa indicated that "the public participation efforts succeeded in creating a sense of ownership in the product". ${ }^{114}$ There was clearly increased knowledge of the constitution and there was strong support for being involved in the process. In general it seemed that individuals believed that the organisers genuinely wanted them to participate and that their submission would be treated seriously, ${ }^{115}$ while the style in which the draft document on the Bill of Rights was presented, with questions and options, suggests that it was indeed a document open for public consultation and not a fait à compli.

It would appear that the process in Northern Ireland has not received the attention that it should have done. The perceived bias of the Commission, the detachment from political structures and the lack of funding, have rendered conditions difficult for the Commission. The result has been that it is not clear that many outside the human rights community in Northern Ireland are either aware of the process of drafting a Bill of Rights or that they consider they should and could have some part to play in it. Many would support the contention that there is enthusiasm on the part of the Commission to make this consultation process effective for all sections of society but some political parties, drawn along traditional divides, lack the desire to support the process.

\section{CONCLUSION}

The Human Rights Commission is required to submit proposals to the Secretary of State for Northern Ireland and that such proposals will be enacted in Westminster legislation. ${ }^{116}$ Thus, it could be argued even if the drafting process has achieved in instilling a sense of ownership and participation of the people of Northern Ireland, the final decision is taken out of the hands of its own Assembly and placed in those of the British Government. In this respect, a referendum on the Bill of Rights might help to engage political debate and ownership.

The issues regarding implementation of a Bill of Rights have not been covered in this paper and are dealt with extensively elsewhere. ${ }^{117}$ One issue which, however, is central to the process and sense of ownership is whether there will be one document: "A Bill of Rights for Northern Ireland". There have been alternatives suggested, however, that do not go as far. Firstly, it has been proposed that, on the same basis as the Human Rights Act, other relevant international human rights treaties should be enacted into national law through separate pieces of legislation, either for Great Britain and Northern Ireland or just for Northern Ireland. Particular treaties which have

Assembly's dreams that a constitution would include all South Africans from the start, Murray op cit note 34, at 6.

113 Ibid.

114 Gloppen op cit note 10, at 264.

115 More scepticism came from white South Africans who had less faith in the constitution than the black majority, Gloppen op cit note 10, at 265.

116 See above.

117 See Colin Harvey, in this issue above. . . 
been suggested in this regard include the Council of Europe Framework Convention on the Rights of National Minorities, the United Nations Convention on the Rights of the Child and the United Nations Convention on the Elimination of All Forms of Discrimination Against Women. A second alternative suggests consolidating existing legislation on, for example, issues to do with employment rights or discrimination, into single Acts. A third, even weaker, suggestion proposes passing amended pieces of legislation relating to particular Acts, for example, the Race Relations Acts, again, either for Great Britain and Northern Ireland or just for Northern Ireland.

These approaches, however, miss a valuable opportunity. Having one document, a "Bill of Rights for Northern Ireland" can ensure that the Belfast Agreement and the process of consultation, as indicated above, can be used to work towards a culture of peace and understanding. Drafting one document, with the contribution of all persons, can help to instil a sense of ownership of the resulting contents, and ensure a dialogue between others, that ad hoc amendments of legislation or ad hoc incorporation of treaties cannot.

A single Bill of Rights provides a valuable opportunity not only to deal with the situation specific to the past, but also to create a culture for the future in which the rights of all are realised and protected. In this respect, there have been concerns raised by some that the debate on a Bill of Rights is going beyond the situation which is perceived to be specific to Northern Ireland and taking in wider issues. It is submitted that there should there should not be a narrow interpretation of what this situation is, by considering for example, only issues of religion, but it is necessary to look wider at the society as a whole. ${ }^{118}$ While the rights, for example, of ethnic minorities, gays, lesbians and trans people, persons with disabilities, those who are deaf and even women may not be traditionally associated with the conflict in Northern Ireland, this does not mean that they are not relevant to the situation in Northern Ireland. They should be considered in this process. Considering the amendment of ad hoc pieces of legislation or incorporation of specific treaties does not take a holistic view. This is where a Bill of Rights, one document with a recognition of the past and a vision for a future is essential.

A Bill of Rights is not just useful in its final form, but in the process by which it is created. This process should be seen as part of the transition to a more just society rather than as an end in itself. An opportunity for all the people in Northern Ireland to participate in drafting a document where they can see a clear final single product is essential.

118 McCrudden op cit note 1 , at 8 argues that it "might be misguided to focus a Northern Ireland Bill of Rights only on those rights that address specifically Northern Ireland concerns in a narrow way", such as language, discrimination minority rights, criminal justice, as this "reinforces the idea that human rights are narrowly concerned to further the interests of one community, or are narrowly concerned as part of a strategy of dispute resolution between those communities". He notes the success of $s 75$ of the Northern Ireland Act in uniting groups across communities as something that should be encouraged. 